\title{
Early Criterion to Screen Maize Varieties for Their Tolerance to Aluminium Toxic Soil
}

\author{
Delphine Mapiemfu-Lamaré ${ }^{1, *}$, Sali Atanga Ndindeng ${ }^{1}$, Ajebesone Francis Ngome ${ }^{1}$, Charles Thé ${ }^{2}$, Esaïe \\ Tsoata $^{3}$, Celicard Zonkeng ${ }^{1}$, Mewouo Clarisse Mfopou ${ }^{4}$, Lovelyn Bihnchang ${ }^{1}$, Francis Etame ${ }^{1}$ \\ ${ }^{1}$ Annual Crops Department, Institute of Agricultural Research for Development, Yaoundé, B.P. 2123, Yaoundé, Cameroon \\ ${ }^{2}$ West Africa Centre for Crop Improvement, University of Ghana, Accra, PMB 30 Legon Accra, Ghana \\ ${ }^{3}$ Faculty of Sciences, University of Yaoundé I, Yaoundé, B.P. 812 Yaoundé, Cameroon \\ ${ }^{4}$ Laboratory for Plant, Soil, Water and Fertilizer analysis, Institute of Agricultural Research for Development, Yaoundé, B.P. 2123, Yaoundé, \\ Cameroon
}

\begin{abstract}
Tolerance to aluminum toxicity in maize is usually determined after harvesting. This screening process takes place rather too late in the growth stage of the plant and is not economical. In order to speed up the screening of maize varieties for their tolerance to aluminum toxicity in Cameroon, a parameter that could be easily detected early in the plant growth stage was investigated. Thirteen (13) maize varieties were evaluated in pots containing aluminum toxic soil and amended soil (less acidic). There were two experimental blocks and the maize varieties were arranged in a completely randomized block design with three replications. Young plants were carefully off rooted twenty-one (21) days after planting and soluble phenolic compounds quantified. The results suggested that, phenolic compound production varied with maize variety and the soil type. The amount of phenolic compounds produced on aluminum toxic soil was higher $(10.44 \mathrm{x} 103 \mu \mathrm{g})$ than that produced on amended soil with high organic content $(6.60 \times 103 \mu \mathrm{g})(\mathrm{P}<0.0005)$. Using LSDs of phenolic compound secretion, the 13 varieties were classified into three groups (tolerant, fairly tolerant and sensitive). Ten (10) varieties were tolerant, two were fairly tolerant and one was susceptible. Varieties 91105, 87036, CLA 18, CML 254, CML 247 that were previously unclassified were classified as tolerant to Al toxicity. Variety Exp1 24 that was previously classified as sensitive using using the yield, the interval between anthers and the silk and length of seminal roots was also classified as tolerant using "intact" plants growing under natural conditions confirming that discrepancies may occur when only one method is used for screening. The quantity of phenolic compounds produced in the presence of aluminum could be effectively used to classify maize varieties as tolerant, fairly tolerant and susceptible to soil aluminum toxicity.
\end{abstract}

Keywords Aluminum Toxicity, Cameroon, Early Selection, Phenolic Compounds, Zea Mays

\section{Introduction}

Maize is the third widely cultivated cereal in the world[1]. The improvement of food security which implicates an increase of production is constrained by low soil fertility, poor climatic adaptability of the varieties, irregularity and unpredictability of rains, diseases[2], soil acidity and in particular aluminum toxicity[3].

Acidic soils occupy about $30 \%$ of the earth's surface[4]. In Cameroon, $75 \%$ of soils are acidic[5], where it is responsible for about $67 \%$ reduction in maize yields[6].

Liming, the application of organic and mineral fertilizers are measures that have been used to successfully manage soil acidity in croplands ([7],[8]). Bio fertilizers such as mycorrhizae that help to improve crop tolerance to diseases,

* Corresponding author:

mapidelph@yahoo.fr (Delphine Mapiemfu-Lamaré)

Published online at http://journal.sapub.org/ijaf

Copyright (C) 2012 Scientific \& Academic Publishing. All Rights Reserved adaptability to adverse environmental conditions and yields are also used to counteract soil acidity[9].

The screening and use of maize varieties tolerant to soil acidity constitute an efficient and permanent alternative to increase yields on acidic soils, avoiding enormous losses often observed with sensitive varieties[3].

Some early indicators such as callose (1,3- $\beta$-glucan), appear to be an excellent physiological marker for the identification of maize varieties sensitive to aluminum toxicity ([8],[3],[10],[4][11]. The accumulation of aluminum in the distal part of root tip is another marker to select susceptible maize varieties[12],[13]. Organic acids such as malic acid, citric acid, oxalic acid and tartric acid ([14],[15]) exuded by maize varieties tolerant to aluminum toxicity play an important role in the detoxification of aluminum. In this case, chelates can be made between organic acids and aluminium, making it non-toxic to plants[14]. The extraction and quantification of these compounds permit the selection of maize varieties tolerant to aluminum toxicity.

However, the extraction and quantification of organic 
acids need very expensive infrastructures that are not always available in poor countries. Furthermore, soluble phenolic compounds are also used to screen maize genotypes tolerant to aluminum toxicity because their extraction and quantification is less expensive. Phenolic compounds play a role in various defense reactions to protect against abiotic stresses like aluminum toxicity[16]. Investigations on the role of the exudation of phenolic compounds as a potential mechanism for the tolerance to aluminum toxicity have been performed by[17]. They analysed phenolic compounds from the root tips of pre-germinated maize in Petri dishes with $50 \mu \mathrm{M}$ aluminium and they found that the exudation of phenolics was enhanced with increasing $\mathrm{Al}$ concentration.

The identification of soluble phenolic compounds as a criterion to screen maize varieties tolerant to aluminum toxicity, which are usually done under laboratory conditions using artificial growth media may show some discrepancies in the results when such experiments are carried out under natural field conditions. These discrepancies may be due to the fact that in the laboratory plants are in a controlled milieu, meanwhile it is not the case on the field. It is thus important to screen maize varieties for their tolerance/sensitivity to aluminum toxicity by evaluating their phenolic compound production using 'intact' plants growing under field conditions.[18] had classified the maize varieties using the yield, the interval between anthers and the silk and length of seminal roots. These parameters are recorded late in the plant growth stage, expensive and this classification has not yet been confirmed using phenolic compound production..

\section{Materials and Methods}

\subsection{Experimental site}

This study was done at the Institute of Agricultural Research for Development (IRAD) Regional Center at Nkolbisson ( $\left.11^{\circ} 36^{\prime} \mathrm{E} ; 3^{\circ} 44^{\prime} \mathrm{N}\right)$ in a 'screenhouse' with natural conditions (short dry season with mean daily rainfall and temperature of $4 \mathrm{~mm}$ and $30{ }^{\circ} \mathrm{C}$ respectively).

(i) Plant material: Thirteen maize varieties were used and their presumed level of tolerance or sensitivity to aluminum acidity[18] is presented in Table 4 .

(ii) Soils used: Two types of soils were used in this experiment. An oxisol sampled from Nkoemvone (South Cameroon), where the soil is acidic and high in aluminum content. The second type was a garden soil collected from Nkolbisson, rich in organic matter. The chemical properties of the soil samples were analyzed at the laboratory of soil analysis at IRAD Nkolbisson-Yaoundé using methods described by[19].

\subsection{Experimental design}

There were two experimental blocks and the maize varieties were arranged in a completely randomized block design with 3 replications. The main variable was soil type (1. acidic soil with high aluminum content, and 2. amended garden soil with high organic matter and the secondary variable was maize variety). The treatments were applied in a randomized block design with 3 replications. The maize varieties were planted in 5-litre pots and each pot had 4 grains of maize, each in a hole. Watering was done every two days.

\subsection{Extraction and quantification of phenolic compounds}

All the plants were off-rooted twenty-one (21) days after planting and the roots washed with distilled water. The roots were oven-dried at $40{ }^{\circ} \mathrm{C}$ till constant weight was recorded. The phenolic compounds were extracted from $0.5 \mathrm{~g}$ dry matter of each maize variety according to the method described by[20].

\subsection{Statistical analysis}

The General Linear Model (GLM) of the Statistical Package for Social Sciences (SPSS) version 10.0 was used to analyse the variance between the various treatments. The least significant difference (LSD) of the means of phenolic compounds from different classes of maize varieties grown separately on aluminum toxic and amended soil with high organic content was compared. LSD were used to confirm the classification made earlier by[18] and to classify unclassified maize varieties used in the present study.

\section{Results}

\subsection{Chemical analysis of soil samples}

Aluminum toxic soil, of $\mathrm{pH}$ (water) 3.40 was poor in nutritive elements, which are calcium $(0.77 \mathrm{cmolc} / \mathrm{kg})$, magnesium $(0.33 \mathrm{cmolc} / \mathrm{kg})$, phosphorus $(56 \mathrm{mg} / \mathrm{kg})$ and potassium $(0.37 \mathrm{cmolc} / \mathrm{kg})$ (Table 1$)$. The cation exchange capacity of this soil was low $(3.52 \mathrm{cmolc} / \mathrm{kg})$. The percentage of saturation by aluminum was 56.80 . The acidity of this soil was therefore due to aluminum toxicity. However, soil without aluminum toxicity (amended soil with high organic content) had a pH (water) of 5.30, contained quantities of nutritious elements, which are calcium $(11.19 \mathrm{cmolc} / \mathrm{kg})$, magnesium $(4.87 \mathrm{cmolc} / \mathrm{kg})$ and phosphorus $(1264 \mathrm{mg} / \mathrm{kg})$. The amended soil with high organic content had a high cation exchange capacity $(17.39 \mathrm{cmolc} / \mathrm{kg})$. Moreover, the soil without aluminum toxicity did not contain any aluminum element, with a percentage of saturation in aluminum equal to zero.

There was a significant variation in phenolic compounds from maize grown on aluminum toxic soil $(\mathrm{F}=12.59, \mathrm{DF}=1$, $\mathrm{P}=0.001)$ those grown in non-toxic soil $(\mathrm{F}=8.49, \mathrm{DF}=9, \mathrm{P}=$ 0.0001 ).

This result suggested that, maize varieties evaluated had different level of phenolic compounds production on aluminum toxic soil. This analysis also revealed a highly significant difference between varieties evaluated for the production of phenolic compounds and that the quantity of phenolic compounds produced in the presence of aluminum 
was statistically different from the quantity produced on amended soil.

[18] had classified the maize varieties used in this study using the yield, the interval between anthers and the silk and length of seminal roots. Eight varieties were classified following this method into three groups: tolerant, fairly tolerant and sensitive to aluminum toxicity. In the present study, these 8 varieties were used with the addition of 5 unclassified varieties. The least significance difference (LSD) of phenolic compounds quantified from the roots of maize varieties grown on aluminum toxic soil was compared in the 4 groups (tolerant, fairly tolerant, sensitive to aluminum toxicity and unclassified) (Table 2). The results confirmed the classification made by[18] except that of $\operatorname{Exp}_{1} 24$ which was classified sensitive by[18], but classified tolerant in the present study. In addition, all the unclassified varieties were classified as tolerant.

The amount of phenolic compounds produced on aluminum toxic soil was higher $\left(10.44 \times 10^{3} \mu \mathrm{g}\right)$ than those produced on amended soil with high organic content $(6.60 \mathrm{x}$ $\left.10^{3} \mu \mathrm{g}\right)(\mathrm{P}<0.0005)$. All classes of maize produced similar amount of phenolic compounds on amended soil with high organic content (Table 3) and as such these soil is not recommended for screening of maize varieties for aluminum toxicity.

The characteristics of 13 maize varieties used in this study and their classification based on yield and morphological parameters[6] and the least significant difference (LSD) of phenolic compounds quantified on aluminum toxic soil (Present study) are shown in Table 4

Table 1. Chemical analysis of soils samples used for the determination of phenolic compounds in different maize varieties that are tolerant or sensitive to aluminum toxicity

\begin{tabular}{|c|c|c|c|c|c|c|c|c|c|}
\hline \multirow{3}{*}{ Soil types } & \multicolumn{9}{|c|}{ Soil characteristics } \\
\hline & $\mathrm{pH}$ & $\mathrm{Al}$ & $\mathrm{Ca}$ & $\mathrm{Mg}$ & $\mathrm{K}$ & $\mathrm{Na}$ & CECE & Ala & $\mathrm{P}$ \\
\hline & $\left(\mathrm{H}_{2} \mathrm{O}\right)$ & $(---$ & ------. & $--\mathrm{cmc}$ & $g^{-1}--\cdot$ & - & ------) & $(\%)$ & $\left(\mathrm{mgkg}^{-1}\right)$ \\
\hline Al toxic & 3.40 & 1.99 & 0.77 & 0.33 & 0.37 & 0.06 & 3.52 & 56.8 & 5.60 \\
\hline Amended & 5.30 & 0.00 & 11.19 & 4.87 & 1.19 & 0.13 & 17.39 & 0.00 & 12.64 \\
\hline
\end{tabular}

Table 2. Comparison of different classes of maize varieties that are sensitive, fairly tolerant, tolerant or unclassified to aluminum toxicity using the least significant difference (LSD) of their phenolic compounds quantified from maize grown on aluminum toxic soil for 3 weeks

\begin{tabular}{|c|c|c|c|c|c|}
\hline \multirow{2}{*}{ (I) Class (J) Class } & \multirow{2}{*}{$\begin{array}{c}\text { Difference of means } \\
\text { (I) }-(\mathrm{j})\end{array}$} & \multirow{2}{*}{ Standard error } & \multirow{2}{*}{ Signification } & \multicolumn{2}{|c|}{ Confidence Interval at $95 \%$} \\
\hline & & & & Lower limit & Upper limit \\
\hline Tolerant Unclassified & -661.11 & 1308.09 & 0.62 & -3487.07 & 2164.85 \\
\hline Fairly tolerant & $-4194.44 *$ & 1688.74 & 0.02 & -7842.75 & -546.13 \\
\hline Sensitive & $5472.23 *$ & 1688.74 & 0.006 & 1823.91 & 912053 \\
\hline Unclassified Tolerant & 661.11 & 1308.09 & 0.622 & -2164.85 & 3487.07 \\
\hline Fairly tolerant & $-3533.33 *$ & 1631.48 & 0.050 & -7057.93 & -8.73 \\
\hline Sensitive & $6133.33 *$ & 1631.48 & 0.002 & 2608.73 & 9657.93 \\
\hline Fairly tolerant Tolerant & $4194.44 *$ & 1688.74 & 0.027 & 546.13 & 7842.74 \\
\hline Unclassified & $3533.33 *$ & 1631.48 & 0.050 & 8.73 & 7057.93 \\
\hline Sensitive & $9666.33^{*}$ & 1949.99 & 0.000 & 5453.96 & 13879.36 \\
\hline Sensitive Tolerant & $-5472.22 *$ & 1688.74 & 0.006 & -9120.53 & -1823.91 \\
\hline Unclassified & $-6133.33 *$ & 1631.48 & 0.002 & -9657.93 & -2608.73 \\
\hline Fairly tolerant & $-9666.67 *$ & 1949.99 & 0.000 & -13879.37 & -5453.96 \\
\hline
\end{tabular}

Based on means observed

*Mean difference is significant at 0.05 level.

Table 3. Comparison of different classes of maize varieties that are sensitive, fairly tolerant, tolerant or unclassified to aluminum toxicity using the least significant difference (at $0.05 \%$ level) of their phenolic compounds quantified from maize grown on amended soil with high organic content for 3 weeks

\begin{tabular}{|c|c|c|c|c|c|}
\hline \multirow[b]{2}{*}{ (I) Class (J) Class } & \multirow{2}{*}{$\begin{array}{l}\text { Difference of } \\
\text { means }(I)-(j)\end{array}$} & \multirow{2}{*}{$\begin{array}{l}\text { Standard } \\
\text { error }\end{array}$} & \multirow[b]{2}{*}{ Signification } & \multicolumn{2}{|c|}{ Confidence Interval at $95 \%$} \\
\hline & & & & Lower limit & Upper limit \\
\hline $\begin{array}{l}\text { Tolerant Unclassified } \\
\text { Fairly tolerant } \\
\text { Sensitive } \\
\end{array}$ & $\begin{array}{c}966.67 \\
1388.89 \\
4055.5 \\
\end{array}$ & $\begin{array}{l}1894.22 \\
2445.43 \\
2445.43\end{array}$ & $\begin{array}{l}0.615 \\
0.576 \\
0.111 \\
\end{array}$ & $\begin{array}{l}-2961.71 \\
-3682.63 \\
-1015.96 \\
\end{array}$ & $\begin{array}{l}4895.05 \\
6460.40 \\
91.27 .06 \\
\end{array}$ \\
\hline $\begin{array}{c}\text { Unclassified Tolerant } \\
\text { Fairly tolerant } \\
\text { Sensitive }\end{array}$ & $\begin{array}{c}-966.67 \\
422.22 \\
3088.89 \\
\end{array}$ & $\begin{array}{l}1895.22 \\
2362.51 \\
2362.51\end{array}$ & $\begin{array}{l}0.615 \\
0.860 \\
0.205 \\
\end{array}$ & $\begin{array}{l}-4895.05 \\
-4477.33 \\
-1810.66 \\
\end{array}$ & $\begin{array}{l}2961.71 \\
5321.77 \\
7988.43 \\
\end{array}$ \\
\hline $\begin{array}{c}\text { Fairly tolerant Tolerant } \\
\text { Unclassified } \\
\text { Sensitive }\end{array}$ & $\begin{array}{l}-1388.89 \\
-422.22 \\
2666.66 \\
\end{array}$ & $\begin{array}{l}2445.43 \\
2362.51 \\
2823.74\end{array}$ & $\begin{array}{l}0.576 \\
0.860 \\
0.355 \\
\end{array}$ & $\begin{array}{l}-6460.40 \\
-5321.77 \\
-3189.41 \\
\end{array}$ & $\begin{array}{l}3682.63 \\
4477.33 \\
8522.74 \\
\end{array}$ \\
\hline $\begin{array}{c}\text { Sensitive Tolerant } \\
\text { Unclassified } \\
\text { Fairly tolerant }\end{array}$ & $\begin{array}{l}-40555.55 \\
-3088.89 \\
-2666.66\end{array}$ & $\begin{array}{l}2445.43 \\
2362.51 \\
2823.74\end{array}$ & $\begin{array}{l}0.111 \\
0.205 \\
0.355\end{array}$ & $\begin{array}{l}-9127.07 \\
-7988.44 \\
-8522.74\end{array}$ & $\begin{array}{c}1015.96 \\
181066 \\
3189.42\end{array}$ \\
\hline
\end{tabular}


Table 4. Characteristics of maize varieties (a) and their classification (b) based on the least significant difference (LSD) of phenolic compounds quantified on aluminum toxic and amended soils

(a)

(b)

\begin{tabular}{cccc}
\hline Varieties & Origin & Adaptation & Colour \\
\hline ATP S4 25W & IRAD & Low altitude & White \\
Cam Inb gp1 17 & IRAD & Low altitude & Yellow \\
88094 & IRAD & Mid altitude & White \\
Entrada 3 & IRAD & Low altitude & White \\
91105 & IRAD & Mid altitude & White \\
87036 & IRAD & Mid altitude & White \\
CLA 18 & CIMMYT & Low altitude & Yellow \\
CML 254 & CIMMYT & Low altitude & White \\
CML 247 & CIMMYT & Low altitude & White \\
Entrada 29 & CIMMYT & Low altitude & White \\
M131 & IRAD & Mid altitude & White \\
Exp1 24 & IRAD & Low altitude & White \\
Tuxpeño sequia & CIMMYT & Low altitude & White \\
\hline
\end{tabular}

\begin{tabular}{|c|c|c|c|c|}
\hline \multirow[t]{2}{*}{ Variety } & \multicolumn{2}{|c|}{ LSD of Phenolic compound } & \multirow[t]{2}{*}{$\begin{array}{l}\text { aPrevious Clas- } \\
\text { sification }\end{array}$} & \multirow[t]{2}{*}{$\begin{array}{l}\text { Present classifi- } \\
\text { cation }\end{array}$} \\
\hline & bAluminum toxic soil & bAmended soil & & \\
\hline ATP S4 25W & $23222.22 \pm 785.67$ & $11888.88 \pm 471.40$ & Tolerant & Tolerant \\
\hline Cam Inb gp1 17 & $6999.99 \pm 2985.56$ & $5777.77 \pm 2199.88$ & Tolerant & Tolerant \\
\hline 88094 & $5888.88 \pm 157.13$ & $6222.22 \pm 1257.07$ & Tolerant & Tolerant \\
\hline Entrada 3 & $4888.88 \pm 0.00$ & $5888.88 \pm 785.67$ & Tolerant & Tolerant \\
\hline 91105 & $11999.99 \pm 5342.58$ & $1111.11 \pm 0.00$ & Unclassified & Tolerant \\
\hline 87036 & $8111.11 \pm 1728.48$ & $4555.55 \pm 3299.83$ & Unclassified & Tolerant \\
\hline CLA 18 & $7777.77 \pm 3771.23$ & $7111.11 \pm 0.00$ & Unclassified & Tolerant \\
\hline CML 254 & $4333.33 \pm 157.13$ & $7999.99 \pm 942.81$ & Unclassified & Tolerant \\
\hline CML 247 & $22333.33 \pm 1728.48$ & $13555.55 \pm 314.27$ & Unclassified & Tolerant \\
\hline Entrada 29 & $21111.11 \pm 2514.16$ & $11111.11 \pm 942.81$ & Fairly tolerant & Fairly tolerant \\
\hline M131 & $7777.77 \pm 5028.31$ & $1777.77 \pm 942.80$ & Fairly tolerant & Fairly tolerant \\
\hline Exp1 24 & $9222.22 \pm 2985.56$ & $1222.22 \pm 471.40$ & Sensitive & Tolerant \\
\hline Tuxpeño sequia & $333.33 \pm 157.13$ & $6333.33 \pm 1099.94$ & Sensitive & Sensitive \\
\hline
\end{tabular}

a: Classification by[17]

b: Least significant difference of phenolic compounds

\section{Discussion}

The quantity of phenolic compounds produced in the presence of aluminum was almost double of that produced on soil without aluminum. This result showed that, in the presence of exchangeable aluminum $\left(\mathrm{Al}^{3+}\right)$, maize varieties produce more phenolic compounds as a mechanism of defense against aluminum toxicity[22]. The conception of antioxidant action of phenolic compounds is not novel[21]. The induction of phenolic compound biosynthesis was observed in maize in response to aluminum[15]. Antioxidant action of phenolic compounds is due to their high tendency to chelate aluminium[23].

It can be observed that all maize varieties produced phenolic compounds either on aluminum toxic soil or on soil without aluminum. Maize varieties known as tolerant to aluminum toxicity tend to produce more phenolic compounds when they are planted on aluminum toxic soil[17].

Therefore, extra quantities of phenolic compounds produced in the presence of aluminum show that $A T P S_{4} 25 \mathrm{~W}$ and 91105 exuded more than $10 \times 10^{3} \mu \mathrm{g}$ of phenolic compounds by the effect of aluminum and are revealed as very tolerant to aluminum toxicity. Other maize varieties classified as tolerant using the quantity of phenolic compounds exuded are: M131, Entrada 29, 87036, Cam Inb gp 1 17, CLA 18, CML 247 and $\operatorname{Exp}_{1} 24$.
The variety $\operatorname{Exp}_{1} 24$ that is native of IRAD Cameroon is known as susceptible to aluminum toxicity by its performance on acidic soil. However, this variety was classified as tolerant to aluminum toxicity using quantity of phenolic compounds it produced. This variety may have a different mechanism to tolerate aluminum toxicity such as detoxification of Al by aminoacid metabolism partways[24]

Maize varieties, which are tolerant to aluminum toxicity may possess some physiological mechanisms that permit them produce more phenols when grown on aluminum toxic soil. A sensitive variety, Tuxpeño sequia may not have the physiological mechanisms against the excess of aluminum and is therefore unable to exude phenolic compounds to detoxify its roots from aluminum. Consequently, the growth is inhibited by aluminum, which penetrates into its roots and interferes with its development[12][25]

\section{Conclusions}

Using phenolic compounds exuded the classification of maize varieties as tolerant, fairly tolerant or sensitive made in a previous study was confirmed by this study. Furthermore, unclassified varieties of maize were classified as tolerant using the extraction and quantification of phenolic compounds. As such, the quantity of phenolic compounds produce by maize varieties cultivated in pots with exchangeable 
aluminum can be effectively used as an early criterion to screen maize varieties for their tolerance to aluminum toxic soils.

\section{ACKNOWLEDGEMENTS}

We appreciate the financial and material assistance obtained from IRAD Cameroon during this work.

\section{REFERENCES}

[1] Anonyme, Mémento de l'agronome. Ministère de la Coopération. Paris. pp. 145-146, 1993.

[2] P. Adregbola, Expérience et acquis paysans au Sud du Bénin. In : CIRAD (ed), Production et valorisation du maïs à l' échelon villageois en Afrique de l'Ouest. CIRAD-ORSTOM, pp. 14-19, 1994.

[3] W. J. Horst, A. K. Püsched and N. Schmoll, Induction callose formation is a sensitive marker for genotypic aluminum sensitivity in maize. In Schaffert R. and Moniz A. (eds) Plant Soil Interaction at low $\mathrm{pH}$. Kluwer Acad. Publishing, Netherlands, Plant and Soil vol. 192, pp. 23-30, 1997.

[4] H. R. Uexhüll and E. Mutert, Global extant, development and economic impact of acid soils, Plant and Soil vol. 171, pp. $1-15,1995$.

[5] J. Bindzi-Tsala, Les sols rouges du Cameroun. Une Communication à la Réunion du sous-comité Ouest et Centre Africain de corrélation des sols pour la mise en valeur des Terres, MINREST-FAO, Yaoundé, Cameroun, pp.10, 1987.

[6] C. Thé, H. Calba, C. Zonkeng, E. L. M. Ngonkeu, V. O. Adetimirin, H. A. Mafousson, S. S. Meka, and W. J. Horst, Response of Maize grain yield to changes in acid soil characteristics after soil amendments, Plant and soil vol. 284, pp. 45-57, 2006a.

[7] L. Claudia, Field and laboratory Screening of Maize (Zea mays L.) Cultivars for adaptation on an Acid Al-toxic Soil in Guadeloupe, Diploma thesis, University of Hannover, pp. 71, 2000.

[8] D. Eticha, C. Thé, C. Welker C, L. Narro, A. Stab, and W. J. Horst, Inheritance of Aluminum Resistance in Tropical Maize Population Using Al-Induced Callose formation in Root Apices as Selection Trait, Journal of Experimental Botany vol. 58, pp. 1351-1357, 2005.

[9] D. Nwaga, E. L. M. Ngonkeu, M. M. Oyong, A. Ngakou, M. Abelong M and J. Foko, In soil beneficial microorganism and suitable agriculture production in Cameroon. Current research and perspectives. In: The biology and fertility of tropical soils. TSBF report 1997-1998. pp. 62-63, 2000.

[10] M. Sivaguru and W. J. Horst, The distal part of the transition zone is the most aluminum sensitive apical root zone of Zea mays L. Plant physiology vol. 116, pp. 155-163, 1998.

[11] M. Llugany, N. Massot, H. A. Wissemeier, C. Posscheriender, W. J. Horst and J. Barcelo, Aluminum Tolerance of Maize Cultivars as Assessed by Callose Production and Root Elon- gation. Z. Pfanzenernährung Bodenkunde vol. 157, pp. 447-451, 1994.

[12] T. Garzón, B. Gunsé, A.R. Moreno, A. D. Tomos, J. Barceló, C. Poschenrieder, Aluminium-induced alteration of ion homeostasis in root tip vacuoles of two maize varieties differing in Al tolerance Plant Science 180, pp. 709-715, 201

[13] P. A. Miguel, J. E. Shaff, H. S. Manslank, A. V. M. Calvalho and L. V. Kochian, Aluminum resistance in maize cannot be solely explained by root organic acid exudation. A comparative physiological study, Plant Physiology vol. 137, pp. 231-241, 2005

[14] L. Hans, F. C. Stuart and L. P. Thij, Plant physiological Ecology. Printed In USA. pp. 239-298, 1998.

[15] W. J. Horst, Fitting maize into sustainable cropping systems on acid soils of the tropics. IAEA - TECDOC - vol. 1159, pp. $47-59,2000$

[16] B. Winkel-Shirley, Biosynthetisis of flavonoids and effects of stress. Current Opinion on Plant Biology vol. 5, pp. 218, 2000 .

[17] P. S. Kidd, C. Poschemieder and J. Barceló, Does root exudation of phenolic play a role in aluminum resistance in maize (Zea mays L.)? Horst W. J. et al., (eds). Plant nutrition - Food security and sustainability of agroecosystems. Kluwer Acad. Publ. Netherlands. pp. 504-505, 2001.

[18] C. Thé, H.A. Mafouasson, H. Calba, P. Mbouemboue, C. Zonkeng and W.J. Horst, Identification de groupes hétérotiques pour la tolérance du maïs (Zea mays L.) aux sols acides des tropiques. Cahiers Agricultures vol. 15, pp. 337-346, 2006b.

[19] E.Van Ranst, M.Verloo, A. Demeyer and J. M. Pauwels, Manual for the soil chemistry and fertility laboratory. Analytical methods for soils and plants equipment and management of consumables. University of Ghent. Laboratory of Analytical Chemistry and Applied Ecochemistry, 1999.

[20] L. Nana, Composés phénoliques et résistance du cacaoyer (Theobroma cacao L) au Phytophthora megakarya. Thèse de Doctorat 3ème cycle Université de Yaoundé, 131 p. 1991.

[21] W. Bors, W. Heller, C. Michel and M. Saran, Flavonoids as antioxidants : determination of radical-scavenging effeciency. Meth. Enzymol. 186, 343pp, 1990.

[22] R. Tolrà, J. Barceló, C. Poschenrieder, Constitutive and aluminium-induced patterns of phenolic compounds in two maize varieties differing in aluminium tolerance, J. Inorg. Biochem. 103 (2009) pp. 1486-1490.

[23] C.H. Jung, V. Maeder, F. Funk, B. Frey, H. Sticher and E. Frosserd, Release of phenols from Lupinus albus L. Roots exposed to $\mathrm{Cu}$ and their possible role in $\mathrm{Cu}$ detoxification, Plant and Soil vol 252, pp. 301, 2003.

[24] Y. Li, H. Lu, X. Fan, C. Sun, D. Qing, H. Dong, L. Wang, Physiological responses and comparative transcriptional profiling of maize roots and leaves under imposition and removal of aluminium toxicity. Environmental and Experimental Botany 69, pp. 158-166, 2010

[25] H. Matsumoto, H. Motoda, Aluminum toxicity recovery processes in root apices. Possible association with oxidative stress, Plant Science 185-186, pp .1-8, 2012 